\title{
Patterns of Democracy Matter in the COVID-19 Crisis
}

A Comparison of French and German Policy Processes

Nils C. Bandelow, Patrick Hassenteufel and Johanna Hornung

\section{OpenEdition}

\section{Journals}

Electronic version

URL: https://journals.openedition.org/irpp/1788

DOI: $10.4000 /$ irpp. 1788

ISSN: 2706-6274

\section{Publisher}

International Public Policy Association

Printed version

Date of publication: 15 March 2021

ISSN: 2679-3873

\section{Electronic reference}

Nils C. Bandelow, Patrick Hassenteufel and Johanna Hornung, "Patterns of Democracy Matter in the COVID-19 Crisis", International Review of Public Policy [Online], 3:1 | 2021, Online since 15 March 2021, connection on 17 June 2021. URL: http://journals.openedition.org/irpp/1788 ; DOI: https://doi.org/ 10.4000/irpp. 1788

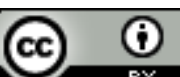

International Review of Public Policy is licensed under a Creative Commons Attribution 4.0 International. 


\title{
Patterns of Democracy Matter in the COVID-19 Crisis
}

\author{
A Comparison of French and German Policy Processes
}

\section{Nils C. Bandelow}

Institute of Comparative Politics and Public Policy (CoPPP), Technische Universität Braunschweig, Germany

\section{Patrick Hassenteufel}

Université de Versailles-Saint-Quentin-Paris-Saclay / Laboratoire Printemps (UMR 8085), France

\section{Johanna Hornung}

Institute of Comparative Politics and Public Policy (CoPPP), Technische Universität Braunschweig, Germany

\section{Abstract}

COVID-19 poses a new challenge to governmental decision-making. With a great level of uncertainty regarding the roots, distribution, prevention, and effects of the pandemic, and with scientific insights and recommendations changing on a daily basis, politicians face the difficult task of reacting quickly but justifiably to the developments. Neo-institutional perspectives of policy research can contribute to the understanding of similarities and differences in strategies to deal with the pandemic by focusing on the interrelationship of institutions and the policy process. A comparison of France and Germany highlights the effects of different patterns of democracy. In what way does the national institutional setting, particularly federalism and centralization, contribute to decision-making? How are political decisions instrumentalized in public debates? The findings indicate that the different patterns of democracy in France (unitary majoritarian system) and Germany (federal consensus system) provide distinctive challenges and make it difficult to transfer successful policies from one country to another.

\section{Keywords}

COVID-19, Patterns of Democracy, Federalism, french politics, german politics, Programmatic Action Framework, health policy 


\section{Introduction}

France and Germany share a lot of similarities in their starting position for dealing with the COVID-19 crisis. The two founding countries of the European Union both have Bismarckian health systems, financed by contributions of employers and employees and regulated by the state in cooperation with associations (Reibling, Ariaans, \& Wendt, 2019). With some 67 and 83 million inhabitants respectively, France and Germany are of a similar size and are both located in continental Europe. As neighboring countries, they had their first official cases of SARS-CoV-2 at the end of January 2020. Both countries used some strategies and policy tools similarly, but they differed substantially in other aspects of their reaction to the pandemic. What explains these similarities and differences in crisis policies?

This comparison focuses not only on the impact of past experiences and of the countries' preparedness for the crisis (Capano, Howlett, Jarvis, Ramesh, \& Goyal, 2020), it also looks at the effects of political institutions and the role of actors in the political game of the policy process, as France and Germany represent opposite types of democracy. First case-oriented comparisons of crisis management highlight the relevance of federalism and other elements of power-sharing for COVID-19 policies (Béland, Marchildon, Medrano, \& Rocco, 2021; Huberfeld, Gordon, \& Jones, 2020; Rocco, Béland, \& Waddan, 2020). Accordingly, the following section discusses theoretical expectations regarding federalism, veto players and other institutional and political differences. The third section analyses the preliminary phase of the pandemic policy encompassing the preparation before the first cases were registered. Subsequently the two phases of policy reactions to the two pandemic "waves" are analyzed: the first from January 2020 to the end of July 2020, the second from August 2020 until the development of the first vaccines at the turn of the year 2020/21. The fifth section analyses the links between policy processes and the political game, contrasting the high level of public trust in the German government with the high level of blame concentrated on the French executive. The conclusion deals with a systematic comparison of challenges that different democracies face in pandemic policymaking.

\section{Political institutions and blame avoidance in different democratic settings}

Political institutions influence policy strategies and results in several ways. Institutions contribute to the access of relevant actors to the decision-making process, guide the preferences and opportunities of actors and may even influence the interaction orientation of actors (Scharpf, 1997). Various forms of government also result in different opportunities for politicians to claim credit and avoid blame for particular outcomes (Hinterleitner, 2018; Nelson, 2016; Zohlnhöfer, 2007). Similar to retrenchment policies, most decisions that include prevention and diminishing of the negative effects of pandemics affect large numbers of the public (if not everybody) without providing short-term benefits. Prevention policies cost (public) money. Additionally, reactions to the pandemic often restrict individual rights and freedoms. In democratic regimes politicians rely on public support and therefore tend to avoid unpopular decisions (Weaver, 1986).

Comparing France and Germany, with their opposing patterns of democracy (Lijphart, 2012), leads to contrasting expectations with regard to blame avoidance. The French unitary majoritarian system puts the president of the state (and leader of the majority party) at the center of each decision, at least in times where there is no political cohabitation (success by the opposition to the President in parliamentary elections) ${ }^{1}$. Therefore, it is very difficult for the French

1 - Cohabitation is unlikely to happen since the aligning of the presidential and the legislative terms (the last cohabitation occurred between 1997 and 2002 with a socialist majority in the National Assembly under a right-wing president). 
President to avoid blame for unpopular and unsuccessful decisions. Additionally, the French protest culture comes with a tradition of public rejection and (partly violent) protest against unpopular policies.

Germany's federal-consensus democracy, on the other hand, distributes power and responsibility between different levels of government, several governmental parties and other veto players. These structures produce hurdles to the implementation of policy change (Tsebelis, 2002). At the same time, they provide ways to shift the responsibility for unpopular decisions to other involved actors (Bandelow \& Hassenteufel, 2006). Cooperative political players, such as coalition parties, also offer multiple perspectives of policy problems and can thereby contribute to the expansion of the alternatives discussed in the policy process (Bandelow, 2008).

The relation between political institutions and COVID-19 policies is far from being direct and simple, though. The list of countries that were hit particularly hard by the virus includes federal countries, such as the US, Belgium and Brazil, as well as more centralized countries such as the UK, Sweden and Chile (Colfer, 2020; Huberfeld et al., 2020; Petridou, 2020; Van Overbeke, 2020). Neither the level of democratization nor the general pattern of the distribution of power directly explains variances in the outcomes. These outcomes also varied widely during different phases of the pandemic. Some states were very successful during the first months but were hit hard in winter 2020/21 and vice versa. Therefore, this analysis will focus on the policy process without aiming at evaluating the preliminary outcomes.

Another usual political suspect in the varieties of crisis management is trust in government before the pandemic (Han et al., 2020). However, both France and Germany faced a government crisis before spring 2020. In France, systemic pension reform and other policy decisions were strongly opposed by the yellow vests, a broad contestation movement born in social media during autumn 2018, and by trade unions. In Germany, all parties in the coalition government that was formed in 2018 (CDU, CSU, SPD) have since lost their party leaders due to election failures, internal conflict and decreasing public support. Therefore, it is necessary to explore the different phases of the policy process to identify the conditions for effective COVID-19 policies. First differences may be found by comparing the level of preparedness with respect to the capability of the health system, specific protection equipment, recent pandemic planning, the economic situation, and a legal framework with clear and suitable responsibilities.

\section{Preparedness for the Pandemic}

The first reactions towards the pandemic were influenced by several factors. While this paper focuses on patterns of democracies, other conditions have to be taken into account to separate the role of political institutions from other relevant factors explaining pandemic handling. Some of these can be summarized as preparedness for the pandemic. Preparedness encompasses several aspects, ranging from the health system to economic and societal conditions. Particularly during the first months, the failure of health systems in parts of Italy and the US shed light on the lack of supply of relevant medical and protective facilities in some countries. Comparing the different aspects of preparedness produces a mixed picture for France and Germany.

Germany has a much higher supply of hospital beds, especially intensive-care beds, and provisions for extracorporeal membrane oxygenation (ECMO). France provided only 11 intensivecare beds per 100,000 inhabitants compared with 35 in Germany (Hassenteufel, 2020). The German health system also has a dense provision of specialist physicians in private practice and provides a network of local public health departments. Nonetheless, France also performs 
quite well in terms of health-system comparisons and gets similar or even better evaluations than does Germany (see, for example, GHS Index, 2019, p. 20).

Economic conditions are also quite similar, but indicate that Germany was slightly better prepared for the pandemic than was France (Camous, 2020). Regarding GDP per capita, both Germany (41,340 Euro) and France (36,060 Euro) are above the European Union and the Euro zone average in 2019 (Eurostat, 2020a). The seasonally adjusted unemployment rate in Germany amounted to 3.3 percent in January 2020, before measures were taken to tackle the pandemic. In the meantime, France recorded an unemployment rate of 8.0 percent in January 2020. Considering the total number, France had a seasonally adjusted unemployment rate twoand-a-half times as high as Germany in the time period before the first registered infections (Eurostat, 2020c, 2020d). Taking into account the budgetary policy immediately before the crisis, in regard to the Maastricht criteria, the general government gross debt of European countries to GDP should not exceed 60 percent. Since April 2019, Germany had a national debt of 61.1 percent, which fell to 59.8 percent in the last quarter. The first quarter of 2020, and thus the first quarter of the pandemic, shows an increase to 61.3 percent. In contrast, France recorded a general government gross debt of between 98 and 100 percent in 2019, putting it in fifth to sixth place among the most indebted countries in Europe. Between 2019 and 2020, French government debt increased by 3.1 percentage points to 101.2 percent (Eurostat, 2020b). As stipulated by the European Central Bank, countries with high levels of public debt are more vulnerable to the economic consequences of a crisis (Burriel, Checherita-Westphal, Jacquinot, Schön, \& Stähler, 2020).

Societal structures indicate that, regarding COVID-19, Germany should be slightly more severely affected than France as a result of population density, age structure and the number of people living with two or more chronic diseases. Considering the risk factors of smoking and obesity, which seem to increase the individual risk for severe infection with COVID-19, France was also better prepared than Germany (OECD, 2019, pp. 27, 88, 96). The influence resulting from these numbers is controversial, though. There are other conditions - for example, greeting rituals - which differ between and within the countries and which are difficult to measure. Nonetheless, they may be relevant for the spread of the disease.

Regarding the specific preparedness for a pandemic, both countries showed weaknesses. Although there were pandemic plans (RKI, 2017; SGDSN, 2011), the two countries failed to provide sufficient protection equipment, especially masks for the health system and for the general public. This was partly the result of political responsibilities. In Germany the basic law provides concurrent legislation for the federal state and the Länder, which in practice means that there is federal legislation that is to be implemented mostly by Länder bureaucracies. With regard to the provision of protection equipment, it was unclear to what extent federal agencies, Länder, hospitals or medical associations were responsible for ensuring sufficient stocks.

In France the local and regional authorities lack direct responsibilities and rely on the regional health agencies (ARS) under the authority of the national health ministry. So the central state had full authority (at least at the beginning of the pandemic). Territorial actors criticized the outcome of the central policies given that regional aspects had not been taken into account sufficiently (Hassenteufel, 2020). Hence, the French case provides additional evidence of the poor preparedness of central bureaucracies for the crisis (Bergeron, Borraz, Castel, \& Dedieu, 2020; Gay \& Steffen, 2020), a situation also visible in other countries such as Italy (Capano, 2020).

In summary, the countries showed rather similar weaknesses in their preparation for the crisis. The only obvious difference was the much higher number of hospital beds in Germany. Short- 
comings in protection equipment concerned both countries alike. There are also differences regarding administrative preparedness that mirror the respective patterns of democracy. In France, centralism produced problems through not taking sufficient account of regional differences regarding the provision of all kinds of supplies relevant for the pandemic policy. However, the particular lack of protection masks was a contingent result of former developments only indirectly connected to the French type of democracy. France used to have a stock of 714 million protection masks three years before the crisis started. However, apart from a small remainder of only 117 million masks, they were all destroyed because they were either outdated or not compliant (Hassenteufel, 2020). This was related to the French experience with the outbreak of swine flu in 2009/10, during which France took a pro-active stance (Versluis, Asselt, \& Kim, 2019, p. 92) which was later considered to be an overreaction (see, for this concept, Maor, 2020).

In Germany, federalism enabled internal shifts in responsibilities. On the one hand, there were many access points for organizing pandemic prevention, including the federal state, the Länder and the municipalities, different parties bound together by coalition governments, some 100 sickness funds, private insurance companies, hospitals, and resident doctors. However, multiple responsibilities can lead to rationality traps especially regarding the provision of resources for prevention. They may also result in a confusion of responsibilities at the beginning of a crisis. For example, there is an ongoing debate about the financing of tests and protection provision, given that the social health insurance (SHI) covers only some 90 per cent of the population and therefore does not provide for the rest of the population (mainly civil servants and high earners, covered by state aid and private insurance).

\section{First Phase: January until the End of July 2020}

The European Union provides a regularly updated overview of the development of the pandemic and of each country's measures (ecdc, 2021). The first three European cases of COVID-19 were registered on the $24^{\text {th }}$ of January in France, followed by Germany three days later. Both countries faced a first wave of infections which decreased in the summer of 2020. How did centralist or federalist decision-making structures affect the elaboration and implementation of policies and can they be regarded as obstacles to tackling an acute problem?

One-and-a-half months after the first infections in France and Germany, the WHO gave the COVID-19 outbreak the status of a pandemic. By this time, both countries had established scientific advisory committees to consult with their respective governments. In France, two expert councils were established by the President. More importantly, the President reactivated the (then) "Defence and National Security Council" (CDSN) whose original role had been to provide decisions at times of military crisis. Formally, the President is the supreme commander of the army and responsible for foreign policy, but has no direct authority for internal affairs including health policy. By using a military institution, Emmanuel Macron gained the undisputed leadership regarding pandemic policies. He presides over the council and has full authority over its membership and calling its meetings. Effectively, all major decisions have been made by the council which has met regularly since March 2020 (often once a week), bypassing the weekly cabinet meetings (Rousselier, 2021, Lemarié \& Faye, 2020). The main decisions have been publicly announced by the President before becoming governmental regulations. Parliament was also bypassed by the adoption of an emergency health law at the end of March 2020, giving broad powers to the executive, including the possibility of adopting many measures by governmental decree. Regional and other local authorities were mostly excluded from 
this centralized and presidentialized decision-making process, although there was some leverage for territorial actors when lockdown measures were first lifted in June 2020 (Hassenteufel, 2020, pp. 174-175).

In Germany, on the other hand, most competencies for pandemic policies lie with the subnational level. On the federal level, legislation required decisions by the parliament (Bundestag) and by the Federal Council (Bundesrat). To speed up the decision-making process and standardize measures, the legislator empowered the health ministry to take protective measures at the end of March, 2020. This (first) law on protection of the population in the event of an epidemic of national concern was very controversial and paved the way for the ensuing combination of strict measures decided at the federal level. The law was even amended in May, 2020 and combined with broad financial compensation to cover the effects of the "soft lockdown" for the economy.

The German health ministry recommended the cancellation of events with more than 1,000 participants, but both countries took binding measures only after pandemic status was declared. In March, 2020, most German Länder closed their education and childcare facilities. Germany prohibited major events until the end of August and restricted public offerings such as church services and non-essential retail. In mid-March, 2020, Germany declared contact restrictions which differed depending on the Länder.

Since March, 2020, similar measures were taken in France. Slightly earlier than in Germany, France closed all schools and universities on March $12^{\text {th }}, 2020$. France set up a lockdown, stating that one may leave the house only in exceptional cases essential for life, depending on the completion of an authorization form. This measure, which was stricter than the restrictions in Germany, remained in place until mid-May 2020.

Both countries had a similar and inconsistent strategy towards masks. At the beginning of the pandemic, the wearing of masks was not binding and was declared as not helpful in reducing infections. This came as a surprise as it was quite established knowledge, and even declared in pandemic plans, that masks were useful. Additionally, the experience of Asian countries, such as Japan and South Korea, provided direct evidence for the epidemiological benefit of the use of masks. The strategies changed when masks were available in higher numbers. In Germany, the Robert-Koch-Institut (RKI, the responsible higher federal authority of the health ministry) gave the first recommendation regarding the use of masks in public areas on April $2^{\text {nd }}, 2020$. Almost three weeks later, the first Länder decided to make the wearing of masks obligatory in some public areas. They followed the example of the city of Jena which had already made masks obligatory on April $6^{\text {th }}$, 2020. Jena provided a field test with the impressive result of zero new infections in the first days after implementing the new measure. Under the hard lockdown in France, the wearing of masks was introduced on a voluntary basis until the easing of the confinement on May 11 $1^{\text {th }}, 2020$ and became mandatory from July 20 $0^{\text {th }}, 2020$ in some regions.

Germany established a high number of tests very early. In mid-April 2020, 17 selected people per 1000 inhabitants were tested in Germany. This first testing strategy only included people who had symptoms and who had contact with infected people or who had been in risk areas. Later testing strategies included more groups such as professional athletes and travel returnees. France started with a much lower number of 5.1 tests per 1000 inhabitants and only increased the number of tests significantly in August (Hassenteufel, 2020).

Even more important than the pure number of tests was the testing and the treatment of infected people during the first phase. In Germany, only 20 percent of infected people were 
treated in hospital, while in France 80 percent of tests and 70 percent of treatments were provided by the inpatient sector (Osterloh, 2020). This involved a particular risk of hospitalacquired (nosocomial) infections in France. Even though there is still a lack of reliable data (some numbers for Germany are provided by Schrappe et al., 2020), first reports provide evidence that this may be an important factor in explaining the high number of deaths in France (Vanhems, 2020).

Summarizing the first reactions, both countries established decision-making structures to tackle the new situation. Even though there were pandemic plans, the actors, constellations, and strategies changed multiple times as there were neither rules nor scientific knowledge to rely on. However, the federalism in Germany led to some roles being played by subnational governments, which was not the case in France. The German testing strategy was coordinated by the federal agency, RKI, while the decisions on containment measures were taken by the Länder and mostly coordinated by regular virtual conferences including representatives of both the Länder and the federal state. In France, all decisions were made by the central government and hardly took into account the position of local authorities.

\section{Second Phase: August 2020 to the Turn of the Year 2020/21}

After the relaxation of the situation during the summer of 2020, both countries faced a second increase in infection rates, hospitalizations and deaths of infected people in autumn 2020. This second phase can be seen as a separate case of pandemic reactions. The countries had to react to the results of the first phase: in Germany the outcome was seen as a relative success and the government and scientists enjoyed a high level of trust, while the French President faced strong criticism. The second wave reached its peak in numbers of daily deaths (seven-day moving average) in France in November, 2020, while in Germany the numbers increased until the end of 2020 (Worldometer, 2021).

As France faced comparatively high infection rates in late summer 2020, the national government decided on several measures to be implemented from August, 2020. They were all taken by the central executive and prepared by the "Defence Council". The restrictions were extended to become a curfew related to the regional number of infections. Then a second national lockdown, less constraining than the first one, was decided for the period from the beginning of November 2020 to mid-December 2020 (see timeline). With the first approval of vaccines, the distribution was similarly decided and organized by the French government, on the basis of the recommendations of the National Health Agency (HAS), without including any local authorities.

As in Germany, both the experiences of the first phase and the low numbers in early autumn allowed for a relatively relaxed approach; it took until the end of October, 2020 for restrictions to be renewed by federal and Länder governments, coming into force until the end of November, 2020. The most controversial discussion was not about the measures but about the next step of strengthening the federal health ministry by the third law on protection of the population in the event of an epidemic of national concern, coming into force on November $19^{\text {th }}, 2020$. This "third population protection act", as it was called, further expanded the authority of the health ministry to act without prior consultation of the parliament. This new power was used to decide stricter measures on December $13^{\text {th }}, 2020$. As in France, the federal government (in Germany the Health Minister) issued a regulation to prioritize different risk groups (based on several criteria such as age, housing, profession, and pre-existing diseases). However, as the first group included some eight million people, the Länder were to choose separate subgroups 
to be vaccinated first. This resulted in some Länder starting only with people in retirement and nursery homes, while other Länder also prioritized elderly people and specific risk groups. The heads of the Länder were also included in all measures decided by informal meetings between the 16 Länder governments, the federal government and some experts in winter 2020/21.

The second phase of the pandemic therefore mirrors the vertical structure of both states: although in France the unitary state centralized decision-making and policy implementation, in Germany the regional level still played an important role. This may come as a surprise as the countries established ad hoc institutions to manage the crises and thereby bypassed established political institutions, notably the parliaments.

Figure 1: Timeline of COVID-19 related measures

France

\begin{tabular}{|l|}
\hline government advisory scientific council $11 / 03 / 2020$ \\
\hline closure of schools, universities, day-care centers $12 / 03 / 2020$ \\
\hline lockdown $17 / 03 / 2020$ \\
first relaxations $11 / 05 / 2020$ \\
\hline $\begin{array}{l}\text { Iaunch of the Stop Covid app, travel restriction lifted, } \\
\text { reopening of restaurants and bars } 02 / 06 / 2020\end{array}$ \\
\hline gatherings of up to 5,000 people allowed again $22 / 06 / 2020$ \\
\hline
\end{tabular}

gatherings of up to 5,000 people allowed again 22/06/2020

\section{Germany}

first infection $27 / 01 / 2020$

recommend cancellation of all major events with more than 1000 participants $10 / 03 / 2020$

contact and travel restrictions 16/03/2020

(First) Law for the Protection of the Population 28/03/2020

mandatory wearing of masks applied

throughout Germany 29/04/2020

first relaxations $04 / 05 / 2020$

한

torid-19-

related financial burdens $05 / 05 / 2020$

Second Law for the Protection of the Population 19/05/2020

穿

financial aid resolution of an economic stimulus package of 9.5 billion euros 03/06/2020

start of the Corona warning app 16/06/2020

federal and state governments agree on a pact for the public health service ( 4 billion euros) 07/09/2020

renewed restrictions adopted by federal and state governments come into force until end of November 29/10/2020

Third Law for the Protection of the Population 19/11/2020

stricter measures until 10 January 2021 13/12/2020

federal regulation determines (large) groups to prioritize for vaccination (differently implemented by the states) 18/12/2020 


\section{COVID-19 and the Political Game}

COVID-19 started as a challenge for governmental problem-solving. The first reactions to the new pandemic were made by the respective governments in both countries, relying on expert advice. At least within the very first weeks, there was no relevant partisan conflict or personalization of the new issues. However, as the shortcomings in pandemic preparedness became visible and measures included restrictions and demanded sacrifices that affected population groups differently, pandemic policies became more political. COVID-19 policy was established as a new policy subsystem that was open to different levels of government, political parties, individual politicians, scientists, media and social movements. The actors involved, their strategies, and the policy process follow the conditions of the respective political system.

In Germany, despite the governmental crisis at the beginning of the pandemic, the cooperative federalism enabled a political game with quite a high number of players, which nonetheless produced continuously rising support for governmental policies sustained by the so far comparatively good outcome. Very early on, the government included leading scientists in the communication of its policies. Following statements by the Chancellor, Angela Merkel, and the federal Minister of Health, Jens Spahn, the cabinet pursued a strategy of communicative restraint. The RKI took the responsibility for communicating daily the progress of the numbers and the scientific policy suggestions. This was supported by leading virologists. The media disseminated the pictures from Bergamo, Italy, contributing to the early and broadly accepted perception of the pandemic as a major crisis. The political strategy of "flattening the curve" to secure medical care, especially hospital beds, was not only accepted but distributed by elites from multiple groups in society, including politics, science, and the media. The virologist, Christian Drosten, became a public hero at this time after his team at the Charité in Berlin developed one of the first PCR tests to detect acute infections. Drosten also delivered a regular podcast to explain his interpretation of all developments in state-of-the-art COVID-19 research to a broader public.

Despite the broad support for the governmental policies, there were a couple of public conflicts between individual politicians and scientists which usually combined political, scientific and media logic. The most eye-catching political conflict concerned the succession to Angela Merkel. Her party, the Christian Democratic CDU, was about to elect a new party leader. There were three officially declared candidates, including the Prime Minister of Germany's largest Land, North Rhine-Westfalia (NRW), Armin Laschet (who won the election in January 2021). For his campaign, Laschet declared cooperation with his fellow party member, Jens Spahn, the acting federal Minister of Health. The party leadership of the CDU does not automatically lead to a candidature for the post of federal chancellor, as the CDU has to agree with its sister party, the CSU, whose party leader, Markus Söder, is Prime Minister of Germany's second largest Land, Bavaria. As NRW and Bavaria belonged to the most affected Länder of the pandemic so far, Söder and Laschet could use the pandemic not only to compete for best policies but also to present themselves as suitable candidates for the federal chancellorship.

Both politicians come from the same political camp, but they grew, step by step, into competing roles within the pandemic policies. Laschet cooperated with the virologist, Hendrik Streeck, of the University of Bonn, in NRW, who was responsible for the famous and controversial "Heinsberg study" which claimed that there was a high percentage of asymptomatic infections (Breznau, 2020). Both Laschet and Streeck were portrayed as proponents of rather liberal measures. Söder, on the other hand, took the chance to advocate strong measures for his Land. The first political result of the conflict was broad support for Söder from the media 
and from the public. However, mistakes in the transmission of test results in Bavaria in August 2020 and the still low figures in Germany in late summer endangered the initial popularity of Söder (Serrao, 2020).

Other actors took the chance to establish themselves as advocates of radical views. In particular, the former health spokesman of the parliamentary party of the SPD, Karl Lauterbach, a medical professor himself, took a position as advocate of restrictive precautions. This helped him back into the public eye after being defeated as a candidate for the leadership of his own party in 2019 and losing any formal position in the health-policy subsystem before the crisis. Along with other politicians, virologists and journalists, Lauterbach engaged in several specific personal struggles that often included personal attacks on opponents.

Despite the emotional and personal public debate, there was always broad support for the general governmental strategy that included most elites and the voters of all large parties except the populist right-wing Alternative für Deutschland (AfD). The AfD is the largest opposition party in the recently elected German parliament but has virtually no support from any elites in media and science. Politicians from the AfD, together with some public figures from culture, sports, and above all social media, raised sharp criticism of the governmental strategy, arguing that the virus was not particularly dangerous. The protest movement included far-right actors and conspiracy theorists, but also some people and families that were not convinced by the necessity for strict measures. In contrast to the former conflict on immigration, the AfD has not yet gained any additional public support by promoting the anti-governmental protests (Naumann, 2020).

Even though the government still enjoys a high level of trust and support in Germany, as of winter 2020, there have been some changes. First, the extreme trust in science that arose at the beginning of the pandemic gradually fell in 2020 (Wissenschaft im Dialog, 2020). As the government always publicly emphasized that it took all measures based on "the" scientific evidence (sometimes referring to Angela Merkel's profession of physicist), this could also be interpreted as a loss of trust in government. More importantly, Germany will have 10 elections in 2021, including a general federal election. This has contributed to changing conditions for the political game: Germany is governed by a coalition of Christian Democrats and Social Democrats that traditionally see each other as their main competitor. Additionally, the Green party is needed for most decisions as it participates in 11 out of 16 Länder governments (as of the end of 2020). Therefore, the proximity of election campaigns is a challenge for pandemic policies: the parties have to avoid blame for mistakes and gain credit for successes, which makes it difficult to find quick and consensual solutions. This became visible when Social Democrats made the Christian Democrats responsible for the lack of vaccines in January, 2021.

In France, the pandemic policies also followed the patterns of the political system. The French President and the government, using constitutional tools (decision-making in the Defence Council, delegation of the legislative power to the executive on the basis of an emergency health law), were able to elaborate their policies without facing veto players from other parties or governmental institutions. However, this concentration of authority comes with the price of blame for any failures. France belonged to the group of European countries with the worst results during the pandemic's first wave and the government and the President were made responsible for this outcome by the public and by the political opposition on both right and left.

The mix of pandemic policies and political conflict became obvious with the municipal elections. The decision to maintain the first round on March 15th 2020, just after the closure of schools, universities, restaurants and bars, has been heavily criticized. The governmental party 
was defeated in the main cites and the polls showed very low support for the President. At the beginning of May 2020, 62\% of French people were dissatisfied with governmental policies, compared with $26 \%$ in Germany (Hassenteufel, 2020). Even the Prime Minister, Édouard Philippe, received better results than Macron and was among the very few members of the governmental party to be successful in the second round of the municipal elections, which was postponed until the end of June 2020.

Not surprisingly, Macron shifted the blame for the failure of his policies to Philippe, even if he was re-elected as mayor of Le Havre, and replaced Philippe as Prime Minister at the beginning of July 2020. His successor, Jean Castex, doesn't represent another party wing as both he and Philippe come from the conservative Républicains. However, Castex, a former senior civil servant belonging to the programmatic "custodians" of the healthcare state since the mid-1980s (Genieys, 2010; Genieys \& Hassenteufel, 2015; Hassenteufel \& Genieys, 2020), was responsible for the lifting of the lockdown plan that was implemented after May 11, 2020.

The concentration of political blame on the executive also led to the setting up of two parliamentary inquiry commissions (in the National Assembly and the Senate) looking into the management of the pandemic and to the filing of numerous complaints against members of the government: 150 complaints had been lodged with the Court of Justice of the Republic by midDecember, 2020. It was also at this time that the public prosecutor announced the opening of a vast preliminary investigation into the management of the health crisis, including looking at charges such as "manslaughter" and "endangering the lives of others". The conclusions of the two parliamentary commissions, made public in December, 2020, were very critical and pinpointed several policy failures, particularly the lack of preparedness for the pandemic crises, the lack of coordination in crisis management and the delayed reactions, as explanations of the poor outcomes of the first wave. In addition, the slower start of vaccination in France at the end of December, 2020, compared with other European countries, especially Germany, triggered new criticism from both right- and left-wing oppositions, as well as from local authorities and well-known figures from the medical profession. The yearly survey on confidence in politics, published in February 2021, showed that in France 37\% of the people asked were satisfied with the governmental handling of the crisis (39\% in April 2020), against 56\% in Germany (74\% in April 2020).

This high level of mistrust in France helps to explain the emergence of new protest figures, in particular Professor Didier Raoult, a well-known proponent of the use of hydroxichloroquine to treat COVID-19 patients, who has been supported by parts of the political class, particularly among the hard-right Rassemblement National (RN) and the hard-left La France Insoumise (LFI) parties, as well as the centre-right LR party. Symbolizing the contestation of the medical and political establishment, Raoult received a lot of support across social networks and among the yellow vests. However, compared with the public protests against COVID-19 measures in Germany, the French protests remained relatively small (Soullier, 2020). This is uncommon for France, but can easily be explained by the much higher number of deaths, which legitimized the restrictions.

In summary, both countries experienced a politicization of pandemic policies. In Germany, the leading parties, especially the CDU/CSU, managed to occupy all positions providing relevant public support. Germany also successfully included virologists in the communication strategy. Even though there was a heated political conflict, the core of the policies remained largely untouched. The French majoritarian system, on the other hand, offers very little room for blameavoidance strategies in the context of bad policy outcomes. 


\section{Conclusion: Different Challenges to the Politics of Pandemic Policies}

COVID-19 policy processes differ from everyday policy-making. Governments are confronted with a lack of knowledge about both the type of problem and the effect of their strategies. Nobody could name a working solution at the beginning of the pandemic. Governments were forced to establish new institutions and strategies. At the same time, they were bound by their established rules, agencies, actors, and history. This paper has confronted the neo-institutionalist view of comparative policy research with the politics of the policies to tackle the pandemic.

The comparison of France and Germany provides a complex answer to the question of what explains the similarities and differences of pandemic policies in different types of democracies. Political institutions provide different challenges for each country. The German challenge results from its federal consensus structures, as the German polity brings an obvious and general challenge and a more peculiar challenge often overseen by generalizations of federal countries. The general challenge concerns balancing centralized solutions with clear, unambiguous regulations, on the one hand, and decentralized solutions that take regional situations and preferences into account, on the other. Germany was forced to rebalance its federal state during the pandemic, giving the central state, and especially the federal health ministry, additional competencies. However, while the strengthening of the federal executive may be seen as a problem for democracy as the parliament lost its control options, the Länder level remained important. The heads of Länder governments were included in the informal decision-making. Additionally, the Länder always retained the option of implementing central regulations on a regional basis, using their own leeway.

The specific challenge concerns the enduring conflict between consensus requirements among the various veto players and party competition in parliamentarianism. During the first phase, party competition was primarily the subject of individual conflicts within the parties. However, this changed in the second phase with increasing competition between parties (especially between the coalition parties: SPD and CDU/CSU) due to the proximity of elections. France, on the other hand, has no problem with finding majorities for quick solutions as all the power lies with the President and his supporters. However, this is also a problem for blame avoidance: the President had to be very careful with his decisions because there was a broad protest movement against the government and the "elites" as a whole. The yellow vests in particular, but also left-wing and right-wing politicians, use every mistake in the pandemic policy to delegitimize the President.

A second special feature is based on the centralization of the public debate that forced the President to establish new ad hoc bodies so as to include expertise and legitimacy in his decisions. However, contrary to the German experience, local authorities have not been included in the decision-making process and have only very limited options for implementations that adapt to local circumstances. Thus, local authorities, most of them headed by opposition parties, contribute to the concentration of blame on the President and the government.

The comparison clarifies the fact that political institutions are an indispensable element in understanding different pandemic policies. Patterns of democracy do not explain the level of success of these policies but build the frame that determines which actors and strategies are possible and which particular challenges will be faced. Future research on the long-term performances of COVID-19 policies will have to take into account other explanations. For this task, theories of the policy process provide several variables ranging from policy networks, social identities and programmatic groups (Bandelow, Hornung, \& Smyrl, 2021; Hornung, Bandelow, 
\& Vogeler, 2019) to policy instruments (Dunlop, Ongaro, \& Baker, 2020) and scientific information and learning (Weible et al., 2020). However, the first results of this two-country analysis suggest that further research should concentrate more on comparisons within similar types of democracies as the causalities proved to be much more complex than could be covered by this first research design.

\section{Bibliography}

Bandelow, N. C. (2008). Government Learning in German and British European Policies. JCMS: Journal of Common Market Studies, 46(4), 743-764.

https://doi.org/10.1111/j.1468-5965.2008.00805.x

Bandelow, N. C., \& Hassenteufel, P. (2006). Mehrheitsdemokratische Politikblockaden und verhandlungsdemokratischer Reformeifer. Kölner Zeitschrift für Soziologie und Sozialpsychologie : KZfSS, 46(S1), 320-342.

Bandelow, N. C., Hornung, J., \& Smyrl, M. (2021). Theoretical Foundations of the Programmatic Action Framework (PAF). European Policy Analysis, 7(S1), 14-27.

https://doi.org/10.1002/epa2.1083

Béland, D., Marchildon, G. P., Medrano, A., \& Rocco, P. (2021). COVID-19, Federalism, and Health Care Financing in Canada, the United States, and Mexico. Journal of Comparative Policy Analysis: Research and Practice, early view, 1-14.

Bergeron, H., Borraz, O., Castel, P., \& Dedieu, F. (2020). COVID-19 : Une Crise Organisationnelle. Paris: Presses de Sciences Po.

Breznau, N. (2020). Science by press conference: What the Heinsberg Study on COVID-19 demonstrates about the dangers of fast, open science. Retrieved from:

https://blogs.lse.ac.uk/impactofsocialsciences/2020/08/20/science-by-press-conference-whatthe-heinsberg-study-on-covid-19-demonstrates-about-the-dangers-of-fast-open-science/

Burriel, P., Checherita-Westphal, C., Jacquinot, P., Schön, M., \& Stähler, N. (2020). Economic consequences of high public debt: evidence from three large scale DSGE models. ECB Working Paper, 2450.

Camous, A., Claeys, G. (2020). The Evolution of European Economic Institutions During the COVID19 Pandemic. European Policy Analysis, 6(2), 328-341.

https://doi.org/10.1002/epa2.1100

Capano, G. (2020). Policy Design and State Capacity in the COVID-19 Emergency in Italy: If You Are Not Prepared for the (Un)expected, You Can Be Only What You Already Are. Policy and Society, 39(3), 326-344. https://doi.org/10.1080/14494035.2020.1783790

Capano, G., Howlett, M., Jarvis, D. S. L., Ramesh, M., \& Goyal, N. (2020). Mobilizing Policy (In)Capacity to Fight COVID-19: Understanding Variations in State Responses. Policy and Society, 39(3), 285-308. https://doi.org/10.1080/14494035.2020.1787628

Colfer, B. (2020). Herd-Immunity Acros Intangible Borders: Public Policy Responses to COVID-19 in Ireland and the UK. European Policy Analysis, 6(2), 203-235.

https://doi.org/10.1002/epa2.1096

Dunlop, C. A., Ongaro, E., \& Baker, K. (2020). Researching COVID-19: A Research Agenda for Public Policy and Administration Scholars. Public Policy and Administration, 35(4), 365-383.

https://doi.org/10.1177\%2F0952076720939631 
ecdc. (2021). European Centre for Disease Prevention and Control: COVID-19 country overviews. Retrieved from:

https://covid19-country-overviews.ecdc.europa.eu

Eurostat. (2020a). COVID-19: Statistics serving Europe. Retrieved from:

https://ec.europa.eu/eurostat/data/database?node_code=nama_10_pc

Eurostat. (2020b). General government gross debt (EDP concept), consolidated - quarterly data. Retrieved from:

https://ec.europa.eu/eurostat/databrowser/view/tipsgo20/default/table?lang=en

Eurostat. (2020c). newsrelease euroindicators. Retrieved from:

https://ec.europa.eu/eurostat/documents/2995521/10568643/3-01092020-BP-EN. pdf/39668e66-2fd4-4ec0-9fd4-4d7c99306c98

Eurostat. (2020d). newsrelease euroindicators. Retrieved from:

https://ec.europa.eu/eurostat/documents/2995521/10662618/3-01042020-AP-EN.pdf/be3d73ee-6715-824b-2c23-f0512f12bdc6

Gay, R., \& Steffen, M. (2020). Une Gestion Étatique Centralisée et Désordonnée. Chronique Internationale de l'IRES, 171(3), 122-138.

https://doi.org/10.3917/chii.171.0122

Genieys, W. (2010). The New Custodians of the State: Programmatic Elites in French Society. New Brunswick, NJ: Transaction Publishers.

Genieys, W., \& Hassenteufel, P. (2015). The Shaping of New State Elites: Healthcare Policymaking in France Since 1981. Comparative Politics, 47(3), 280-295. Retrieved from:

http://www.jstor.org/stable/43664147

GHS Index, G. H. S. I. (2019). GHS Index. Global Health Security Index. Building Collective Action and Accountability. Retrieved from:

https://www.ghsindex.org/wp-content/uploads/2020/04/2019-Global-Health-Security-Index.pdf

Han, Q., Zheng, B., Cristea, M., Agostini, M., Belanger, J., Gutzkow, B., . . Leander, P. (2020). Trust in government and its associations with health behaviour and prosocial behaviour during the COVID-19 pandemic. PsyArXiv, Preprint.

https://doi.org/10.31234/osf.io/p5gns

Hassenteufel, P. (2020). Handling the COVID-19 Crisis in France: Politicization and Policy Changes in a Centralized State-led Health System. European Policy Analysis, 6(2), 170-179. https://doi.org/10.1002/epa2.1104

Hassenteufel, P., \& Genieys, W. (2020). The Programmatic Action Framework: An Empirical Assessment. European Policy Analysis, 6(S1), 28-47.

https://doi.org/10.1002/epa2.1088

Hinterleitner, M. (2018). Policy Failures, Blame Games and Changes to Policy Practice. Journal of Public Policy, 38(2), 221-242.

https://doi.org/10.1017/s0143814x16000283

Hornung, J., Bandelow, N. C., \& Vogeler, C. S. (2019). Social Identities in the Policy Process. Policy Sciences, 52(2), 211-231.

https://doi.org/10.1007/s11077-018-9340-6

Huberfeld, N., Gordon, S. H., \& Jones, D. K. (2020). Federalism Complicates the Response to the COVID-19 Health and Economic Crisis: What Can Be Done? Journal of Health Politics, Policy and Law, 45(6), 951-965. https://doi.org/10.1215/03616878-8641493 
Lemarié, A., \& Faye, O. (2020). COVID-19 : le Conseil de défense, où se décide la gestion de crise, est prisé par Emmanuel Macron et décrié par l'opposition. Le Monde. Retrieved from: https://www.lemonde.fr/politique/article/2020/11/11/le-conseil-de-defense-outil-de-gestion-decrise-prise-par-emmanuel-macron_6059306_823448.html (last retrieved from 12 January 2021).

Lijphart, A. (2012). Patterns of Democracy: Government Forms and Performance in Thirty-Six Countries (2. ed. ed.). New Haven, Conn.: Yale Univ. Press.

Maor, M.(2020). Policyoverreactionstyles duringmanufactured crises. Policy\&Politics, 48(4), 523-539. https://doi.org/10.1332/030557320X15894563823146

Naumann, E. B., Annelies G.; Wenz, Alexander; Rettig, Tobias; Reifenscheid, Maximiliane; Möhring, Katja; Lehrer, Roni; Krieger, Ulrich; Juhl, Sebastian; Friedel, Sabine; Fikel, Marina; Cornesse, Carina. (2020). COVID-19 Policies in Germany and their Social, Political Psychological Consequences. European Policy Analysis, 6(2), 191-202.

https://doi.org/10.1002/epa2.1091

Nelson, M. (2016). Credit-Claiming or Blame Avoidance? Comparing the Relationship between Welfare State Beliefs and the Framing of Social Policy Retrenchment in France and Germany. Journal of Comparative Policy Analysis: Research and Practice, 18(2), 138-156.

https://doi.org/10.1080/13876988.2015.1005928

OECD. (2019). Health at a Glance 2019. OECD Indicators. Paris: OECD Publishing.

Osterloh, F. (2020). Warum Deutschland die Pandemie besser übersteht als viele Nachbarn. Ärzteblatt. Retrieved from:

https://www.aerzteblatt.de/nachrichten/113256/Warum-Deutschland-die-Pandemie-besser-ueberstehtals-viele-Nachbarn?rt=d18b697ac2160e14559115c787a92653 (zuletzt eingesehen am 16. Juni 2020).

Petridou, E. (2020). Politics and Administration in Times of Crisis: Explaining the Swedish Response to the COVID-19 Crisis. European Policy Analysis, 6(2), 147-158.

https://doi.org/10.1002/epa2.1095

Reibling, N., Ariaans, M., \& Wendt, C. (2019). Worlds of Healthcare: A Healthcare System Typology of OECD Countries. Health policy, 123(7), 611-620. doi:10.1016/j.healthpol.2019.05.001

RKI, Robert Koch Institut (2017). Strukturen und Massnahmen. Nationaler Pandemieplan - Teil I. Retrieved from:

https://www.gmkonline.de/documents/pandemieplan_teil-i_1510042222_1585228735.pdf (zuletzt eingesehen am 16. Juni 2020).

Rocco, P., Béland, D., \& Waddan, A. (2020). Stuck in Neutral? Federalism, Policy Instruments, and Counter-cyclical Responses to COVID-19 in the United States. Policy and Society, 39(3) 458-477. https://doi.org/10.1080/14494035.2020.1783793

Rousselier, N., (2021). Le Conseil de Défense : dérive autoritaire ou régime de nécesité?. AOC. Retrieved from https://aoc.media/analyse/2021/01/14/le-conseil-de-defense-derive-autoritaire-ouregime-de-necessite/

Scharpf, F. W. (1997). Games Real Actors Play: Actor-Centered Institutionalism in Policy Research. Boulder, Colo.: Westview Press.

Schrappe, M., François-Kettner, H., Gruhl, M., Hart, D., Knieps, F., Manow, P., . . Glaeske, G. (2020). Thesenpapier 4.0. Die Pandemie durch SARS-CoV-2/Covid-19 - der Übergang zur chronischen Phase. Retrieved from Köln, Berlin, Bremen, Hamburg. Retrieved from:

http://www.matthias.schrappe.com/index_htm_files/thesenpapier_4_endfass_200830.pdf 
Serrao, M. F. (2020, 2020-09-04). Kaum Patienten und Tausende freie Krankenhausbetten: Warum Armin Laschet recht behalten hat und Markus Söder irrt. Neue Zürcher Zeitung. Retrieved from: https://www.nzz.ch/meinung/der-andere-blick/welcher-corona-notstand-laschet-hatte-rechtsoeder-nicht-ld.1574981

SGDSN. (2011). Secretariat-General for National Defence and Security: National "Influenza Pandemic" Prevention and Response Plan. Retrieved from Paris:

https://solidarites-sante.gouv.fr/IMG/pdf/PlanPandemieGrippale-Version_Anglais.pdf

Soullier, L. (2020, 2020-08-29). A Paris, un rassemblement « antimasque » aux multiples revendications. Le Monde. Retrieved from:

https://www.lemonde.fr/politique/article/2020/08/29/a-paris-un-rassemblement-anti-masquesaux-revendications-multiples_6050332_823448.html

Tsebelis, G. (2002). Veto Players: How Political Institutions Work. Princeton: Princeton University Press.

Van Overbeke, T. S., Diederik. (2020). High Politics in the Low Countries: COVID-19 and the Political Consequences of Indequate Policy Coordination in Belgium and the Netherlands. European Policy Analysis, 6(2), 305-317.

https://doi.org/10.1002/epa2.1101

Vanhems, P. S.-E., Mitra; Chuzeville, Michel; Marion, Elodie. (2020). Rapid nosocomial spread of SARS-CoV-2 in a French geriatric unit. Infection Control \& Hospital Epidemiology, 41(7), 866-867. https://doi.org/10.1017/ice.2020.99

Versluis, E., Asselt, M., \& Kim, J. (2019). The Multilevel Regulation of Complex Policy Problems: Uncertainty and the Swine Flu Pandemic. European Policy Analysis, 5(1), 80-98. https://doi.org/10.1002/epa2.1064

Weaver, R. K. (1986). The Politics of Blame Avoidance. Journal of Public Policy, 6(4), 371-398. Retrieved from:

http://www.jstor.org/stable/4007281

Weible, C. M., Nohrstedt, D., Cairney, P., Carter, D. P., Crow, D. A., Durnová, A. P., Haikkila, T., Ingold, K., Mc>Connell, A. \& Stone, D. (2020). COVID-19 and the Policy Sciences: Initial Reactions and Perspectives. Policy Sciences 53(2), 225-241.

https://doi.org/10.1007/s11077-020-09381-4

Wissenschaft im Dialog. (2020). Wissenschaftsbaromenter. Retrieved from Berlin:

https://www.wissenschaft-im-dialog.de/fileadmin/user_upload/Projekte/Wissenschaftsbarometer/Dokumente_20/WiD-Wissenschaftsbarometer_2020_Broschuere_final.pdf

Worldometer. (2021). COVID-19 Coronavirus Pandemic. Retrieved from:

https://www.worldometers.info/coronavirus/

Zohlnhöfer, R. (2007). The Politics of Budget Consolidation in Britain and Germany: The Impact of Blame Avoidance Opportunities. West European Politics, 30(5), 1120-1138.

https://doi.org/10.1080/01402380701617498 